\title{
BIBLIOGRAPHY
}

1. S. Holth.-Kinéscopie, nouvelle méthode de détermination de la réfraction oculaire. Ann. d'Ocul., T. CXXVII, Avril, 1902.

2. Quelques considérations sur l'historique de la kinéscopie. Ann. d'Ócul.. T. CXXIX, Mars, 1903.

3. - Nouveau procédé pour déterminer la réfraction oculaire-la Skiakinéscopie. Ann. d'Ocul., T. CXXXI, Juin, 1904.

4. Trantas.-La Vélonoskiascopie. Bull. et Mém. de la Soc. Frang. d'Ophtal., p. $273,1921$.

5. R. Krämer.-Bemerkungen zur Frage der Velonoskiaskopie. O. G. in Wien, 21 Feb., 1927 ; Zeitschr. f. Augenheilk., Vol. LXII, pp. 111-113, 1927.

6. Trantas.-Ueber die Velonoskiaskopie, wie ich sie derzeit ausübe. O. G. in Wien, 20 Juni, 1927; Zeitschr.f. Augenheilk., Vol. LXII, pp. 343-362, 1927.

7. S. Holth.-Kinematoscopia subjectiva. Klin. Monatsbl. f. Augenheilk., Vol. LXXXIII, pp. 1-7, 19.9.

8. Die Montierung der Objektscheibe mit dem Licht- "punkt" bei Kinematoscopia subjectiva. Klin. Monatsbl. f. Augenkeilk., Vol. LXXXIII, p. 562, 1929.

9. H. K. Müller.-Zur Theoı ie der Velonoskiaskopie. Zeitschr.f. Augenheilk, Vol. LXXX, pp. 113-123, 1933.

10. R. Krämer.-Bemerkungen zur sogenannten Velonoskiaskopie von Trantas. O. G. in Wien, 19 Nov., 1934 ; Zeitschr. f. Augenheilk., Vol. LXXXV, pp. 300-309, 1935.

\section{A RATIONALIZED MIRACLE IN MEDIAEVAL ENGLAND}

BY

W. J. Rutherfurd, M.C., M.D.Glasg.

MANCHESTER

THE first 42 leaves of the Bodleian MS. 859 contain a contemporary copy of a collection of letters made between the years 1381 and 1406 or thereby, by Gilbert Stone, canon of Wells.

Dr. E. F. Jacob, the Professor of Mediaeval History in Manchester University, discussed this collection in the Bulletin of the John Rylands Library for July, 1933 (Vol. XVII, No. 2), and his article contains the following story of mediaeval superstition associated with quasi-miraculous healing of a case of eye disease. Gilbert Stone was registrar to Ralph Erghum, Bishop of Salisbury, and wrote on behalf of the latter "to the Bishop of Lincoln urging him to take steps 'against those committing idolatry at the new well near Bustlesham' (Bisham).* Certain persons, 'blinded by the phantasy of diabolical deceit' had been worshipping the well and paying profane and heathen devotion

- In Berkshire; on the south bank of the Thames uest of Maidenhead. 
to a bird's nest hard by. The passage had best be left in its original form :-

Et pro eo quod, ut dicitur, in eodem fonte, iuxta quem in quodam arbore insuper nidificans quedam duis manibus hominum in nido suo tacta illorum, ut asseritur, non recessit, ymmo quia (sic) domestica et satis domita in nido reposita pacifice requievit, lippus quidam vir fantasticus, suos nuper lauans oculos defluentes estu feruido autumpnali* adustos et potu superfluo plus solito humectantes, oculorum suorum lippitudines frigore aquatico naturaliter operante refrigescere senciebat, hoc nunc reputat pro miraculo multorum erronie credentium ceca lenitas scandalizans; unde modernis temporibus ad fontem eundem tanquam ad locum sanctissimum multi confluunt, et ibidem offerunt et adorant. Quorum quidam in nidum dicte auis, vile gizofilacium suis et pullorum suorum stercoribus maculatum, es iactant, et nephanda manu prophanas oblaciones turpissima deuotione reponunt, in sancte matris ecclesie scandalum, fidei catholice preudicium, perniciosum exemplum plurimorum, ac ipsorum sic ut premittitur ydolatrantium grave periculum animarum.

The bishop had the well sealed up, but it was no good: the wretched people of Wycombe and Marlow $\dagger$ opened it again, and in spite of Erghum's warnings and express prohibitions continued their worship; he therefore requests his brother of Lincoln to have the penalties incurred by such conduct duly proclaimed in the churches (Jacob, Ibid., pp. 288-9).

I am not as convinced as is Professor Jacob that these 14th century peasants had been worshipping or paying devotion to the bird's nest. They seem to have been using it as an offertory, its situation in the tree beside the well suggesting such a use. It was to the well that the people had gone tanquam ad locum sanctissimum, and they left their pence in the nest in the same way as they were accustomed to leave their offerings when they went either to church or to some place of authorized pilgrimage and acknowledged sanctity.

* What bird is it that nests in a tree during the heat of autumn within sight and reach of passers by ? If the nest had been in the church tower or in a hole in a wall one might have thought of $a^{\circ}$ domestic pigeon, as it will rear one brood after another right through the season; but it would hardly nest in a tree. One must think of some bird rearing a second brood late in the season, probably a thrush or a blackbird.

† In Buckinghamshire; both places being north of the river, and so in the diocese of the other bishop who was being asked to take action in the matter. 